\title{
Causality and its Ethical Status in al-Ghazali's Epistemological System
}

\author{
SOBHI RAYAN 1
}

\begin{abstract}
This article deals with the issue of causality and its ethical status in al-Ghazali's epistemological system, which is connected with the issue of Jabr and ikhtiyar (compulsion and choice); the issue of al-šabäbiyya and tawakkul (causality and reliance), i.e., dependence on God and trust in him; and the issue of work. These issues are based on the relationship between Man and God, be He exalted, and on other issues involving the components of Man himself. Al-Ghazali seeks to revive the necessary relationship between Man and God, be He exalted. tawhïd (the unity and oneness of God) is the existential origin and epistemological example from which relationships between Man and himself, people and nature are derived, and the establishment of human work, physical or mental, is based on the knowledge of tawhid, which guarantees the process of this work will reach the end for which it was created.
\end{abstract}

Keywords: causality, ethics, al-Ghazali, Sufism, tawhid

This article deals with the issue of causality and its relationship with ethics in al-Ghazali's epistemological system, where he connects causality and Man's actions through a treatment of the issues of jabr (compulsion), ikhtiyar (choice), and tawakkul (reliance). Al-Ghazali sought to establish ethics on principles of certainty by referring them to their epistemological and existential origins, relying on science, knowledge, and work to achieve moral elevation. This conceptualization required that he deconstruct the relationship between human action and its existential principle because the reality of this connection affects the meaning of morals themselves.

This approach has led researchers to draw different conclusions, some of which claim that alGhazali rejected rational thinking and favored Sufism. "Al-Ghazalı's extreme views have had a long life in both Islamic and Western philosophy. He provided a basis for Süfism and for a rejection of rationalist philosophy that has retained influence to some extent even into modern times." (Naify 1999: 197). However, al-Ghazali's use of formal logic to raise objections against his rivals and to confirm his claims emphasizes his commitment to rational thinking.

"The study of the Maqsad al-Asna fi Sharh Ma'ani Asma' Allah al-Husna, al-Iqtisad fi'lI'tiqad and the Tahafut al-Falasifa. Even in works where the Ash'arite view of divine predestination prevails; the use of Aristotelian logic - intended to rebuff philosophical inconsistencies - has led al-Ghazali to absorb some philosophical constructs" (De Cillis 2004: 4).

\footnotetext{
${ }^{1}$ Sobhi Rayan, Ph.D., Chairperson of the Islamic Studies Master's Degree Program at Al-Qasemi Academic College of Education, Baqa-El-Gharbia, Israel 3010000, email: sobhi.rayan@gmail.com.
}

https://doi.org/10.24035/ijit.14.2018.010 
Some researchers claim that al-Ghazali's search for the existential origin reduced his interest in the search for Man's will: "The primary purpose of Ghazali's argumentation during his time was to ensure God's freedom of will. His position on human free will was perhaps intentionally ambiguous, secondary to the theological debates of the time (Macksood 2015). Furthermore, attributing Man's actions to God's will decreases dependence on the mind:

"The faithful formulate guidelines for ethical behavior by careful attention to God's will and command codified in the Quran-Hadith-Shari'a synthesis, not by undue reliance on 'Aql (reason)" (Awn 1983). On the other hand, al-Ghazali describes those who deny mushahadat (visions) beyond the five senses as "sophistical" and "skeptical," and as "those who are skeptical of things perceptible by the senses." He describes them also as "apostates" and "disbelievers" who deny the existence of the world of al-malakūt (the spiritual realm of sovereignty), who limit knowledge to the five senses only and deny "ability," "will," and knowledge because they are not perceived by the five senses, and thus, they stay at the lowest level of the world of shahāda (witnessing and testimony) by the five senses (al-Ghazali 1983 (4): 252).

Some researchers maintain that al-Ghazali's discussion on the issue of tawhild led to his refutation of Man's free will: "Sufis are generally considered to be determinists. They believe that real tawhīd implies determinism. Al-Ghazali, in his account of determinism, attempts to refute several arguments for free will, such as the arguments from responsibility, from ordinary use of language, and from agent-causation" (Zaroug 1997). Al-Ghazali, however, attributes everything in the world of mulk wa al-shahada (dominion and witnessing) to tawhīd, which is the epistemological and existential origin. "Tawhid sees that everything is caused by the causer of causes, who does not look at the means, but sees them as exploited things that have no judgement, and the believer in this is a certain one" (al-Ghazali 1983 (1): 74). An analysis of these relations between Man and God, and Man and himself, requires a critical treatment of fundamental issues, like the questions of Jabr and ikhtiyar, causality and reliance, and reliance and the question of work.

\section{The Issue of Jabr and Ikhtiyar (Compulsion and Choice)}

Knowledge of tawhīd and the establishment of actions based on causes bequeaths a certainty that causes, phenomena, and events are exploited things that come from God, and they are pure compulsion and do not act out of their free will. Here, a question related to Man's actions arises: Are they jabr or ikhtiyar? That is, are they determined by predestination or free will? If they are compulsory, they contradict the idea of free choice as a condition for responsibility that entails accountability: reward or punishment. "The problem becomes one of more than academic importance when we try to reconcile the moral responsibility of man with the belief in the absoluteness of God's decrees"(Pennings 1941).

Al-Ghazali gives answers to this issue at two different levels: the first is derived from the knowledge of mukashafa (the unseen behind the veils), which means lifting the veil and disclosing the divine irradiation of the essence, which connotes gaining familiarity with things unseen behind the veils: "If the veil is lifted, you would know that ikhtiyar itself is 'compulsory'; thus, he is compelled to choose". It is clear here that al-Ghazali advocates al-jabriyya (determinism), but the concept of jabriyya here is not contradictory to the concept of ikhtiyar, because this contradiction is external and not real or internal, and this is what characterizes the world of Shahada (witnessing and testimony). The world of malakut is God's world, and therefore we do not find contradictions in it, in 
essence"(al-Ghazali 1983 (4): 254). Looking at this issue through the perspective of the world of 'alam al-shahada (testimony and witnessing), separately from the world of malakut, the unseen world of God, undoubtedly leads to the argument that there is a contradiction but considering the world of malakut as an extension of the world of shahada removes that contradiction. The human being who has reached the rank of mushahada (vision) of the unseen hidden world of malakut can see these issues clearly because he is able to go beyond the veils that separate him from the factions of things and their origins in the unseen world of malakut and perceive the origin of causes and their order.

'Ilm al-mu'amala (knowledge of practical religion) represents the second level, on which Ghazali depends for his clarification of Jabr and ikhiyar, depending on the opinion of the mutakallimūn (exponents of 'illm al-kalam who defended the Muslim religion), who classify the actions of human beings into three types (al-Ghazali 1983 (4): 254):

1. Natural actions, such as Man's sinking in water if he attempts to stand on it. This is a compulsory action; it does not happen by Man's will or choice.

2. Voluntary acts, such as breathing, which is an operation that stems from Man's will, but its occurrence is necessary because Man cannot live without breathing, and thus, breathing is a necessity and Man is compelled to want it.

3. Optional actions, such as writing. The external aspect of this type of action is connected to Man's will in the sense of his performing or not performing the action from the point of view of the will itself. In order to avoid harm, Man judges things that suit him without hesitation. For example, he blinks his eye without forethought if you put a needle near it, because he realizes without thinking or deliberation that it is good to do so. This type of action stems from knowledge and will through Man's observations and hidden knowledge.

However, the things that the mind hesitates to judge are actions that it does not intuitively take to be good and which require thinking in order to distinguish them from other actions and to determine that they are the best options. When the goodness of the action appears in the mind, the choice takes place. Thus, the operations of Man's will are subject to the judgments of sense and mind, "The will is nothing more than a distinguishing something like him" (al-Ghazali 1988: 69). For some actions, choices are made spontaneously and intuitively; other actions are performed after the working of the mind. In both cases, Man chooses what is good for him, as it is unreasonable that he would choose what is evil for him. Choices are made between "a good" and "an evil" or between "two evils" and "two goods."

People might differ in their choices, which is due to differences in their minds. Man chooses what his mind tells him is "good" for him. This relativity makes people's choices different or contradictory. The difference between free will and choice is quantitative: "Will suggests no limit or range from which to choose, choice connotes a closed number of alternatives"(Alon 1980). Man's actions are connected to Will as "an adjective by which the actor outweighs one of his actions of doing or leaving. it does not relate in inclination and necessary, may be related to will and hatred". Ability which is known as "an adjective by which it can act and leave" (al-Taftazani 1989: 337). Will is attributed to the judgments of sense and mind; "ability" is employed by the will; "movement" is employed by ability.

Muslims disagreed among themselves and were divided into three Firaq (sects) regarding the question of Jabr and ikhtiyar. Al-Mu'tazila attributed voluntary actions to Man and accorded absolute responsibility for actions to Man himself. However, al-Qadariyya maintained that qadar and its good and evil come from Alla, be He exalted, and that Man is not responsible for his actions. The Ash'arites 
believed in kasb as a response to the Mu'tazila and Qadariyya, which is the attribution of the creation of actions to God, but they attributed kasb to Man, who constitutes a place where God's power flows. al-Taftazani distinguishes between creation and kasb: "What happens to the action which is unique of the Creator is creation, and what happens to the action not with the unique of the creator is kasb" (al-Taftazani 1998: 403). According to this doctrine kasb all human actions are the creation of divine power. Those actions ordinarily regarded as voluntary differ from the involuntary in that they are created with will and power. The created power in humans, however, has no causal efficacy. What is ordinarily regarded as its effect is in reality created for it by divine power (Marmura 2002).

Al-Juwayni who was one of the masters of Ash'ariyya and al-Ghazali's teacher, says that the "denial of Man's ability and capability is not rejected by reason and common sense, but proving ability with no effect generally is the negation of ability originally. As proof of the effect when he does not act is like denial of the effect, especially that conditions at their original states are not described by terms of existence and non-existence.

It is necessary then to attribute a slave's action to a real ability rather than to events or humans, as the human being feels he is independent in his creation from non-existence. Though the human being feels he is able, he feels he is not independent. The existence of the action depends on ability, and the existence of ability depends on another cause; the relation of ability to that cause is like the relation of the action to ability; moreover, a cause is dependent on another cause till it reaches to the cause of causes, God, who is the creator of causes and their effects (al-Shahrastani 1986: 99). Al-kasb in this meaning is a concept that consists of Man's acts and his ability; he is independent in his actions and chooses them, and they are connected to his ability, but Man's ability is not independent but is connected in its existence to God, be He exalted: "Man is responsible for what is his. Now, at the moment of creating a certain act, God created in him a certain power which corresponds to the act. In Virtue of this power, which constitutes his dominion over the act, he becomes responsible for it (Power 1913). This means that the human being chooses his actions, and therefore, he is responsible for his choices, but these actions depend on Man's ability as a condition for his actions, and he is compelled to do them rather than choose them. The vagueness of the concept of kasb, which combines two contradictory things - jabr and iktiyar - does not resolve the complexity of the issue, because if Man is a place through which God's everlasting ability flows, with what right is he asked about his actions? And how can his action be chosen and his ability to act be a "compulsion"?

Al-Ghazali denies the existence of causality between knowledge and will, ability and movement, because the belief in emanation of these things from each other means the occurrence of something that is not done by God's ability. Al-Ghazali reads the emanative arrangement primarily in gynecological terms, thus challenging the idea that emanation is utterly incompatible with the 'orthodox' doctrine for which God is the Creator, as argued by his Ash'arite peers (De Cillis 2014: 4). This occurrence is attributed to a conditional order, which indicates the precedence of the condition to the conditioned. It is possible to say that al-Ghazali was faithful to his commitment to logic, and without doubt he is a well-known logician. He insists on the existence of the conditional relationship between things or events, which is a logical relationship that is characterized by "necessity." At the same time, he excludes a causal relationship because it is a realistic and not a logical one, which indicates Zann (speculation) and probability. Al-Ghazali attributes all maqdurat (objects of the power of ability) to God's ancient everlasting ability. He argues that the real doer/Creator is Allah (God), be He exalted: 
None of the relations just described is causal.... In all cases the rewards or the moral progress are bestowed by God through his grace. Here once again, God is the only cause, and He is under no necessity (Hourani 1976).

Al-Ghazali distinguishes between God (as a creator and an inventor) and Man (as a doer), that is, Man is the place in which God created ability after he created will and knowledge in him. Thus, ability was connected with will and movement, and connected the "condition" and the "conditioned." Man was connected with God's ability in a relation of cause and effect (ma'lul with 'illa), and there was a connection between (1) the "inventor" and the "invented" and (2) anything that has some connection with ability. The one who has ability is called "doer", regardless of the type of connection. Thus, the executioner is called a murderer, and the prince is called a murderer, because murder is connected to their power, but in two different aspects, and therefore, they are called "doers". Furthermore, the gladiator is called a murderer, and the prince/emir is called a murderer because murder is connected to their abilities, but in two different aspects. Therefore, both are called "doers." In addition, al-muqdurat (the objects of ability) are connected to the two abilities (al-Ghazali 1983 (4): 89).

The natures of the objects and events themselves have no independent status. They are only as they are because of the will of God, and so there is nothing in the nature of things and events which are possible which makes them inevitable (Leaman 1996). Al-Ghazali mentions three different types of connection: conditional, causal, and creative. Each ability is connected with one type of connection, which constitutes the place of ability, with is called the "actor". In this case, Man is called an "actor". Man's actions take on two aspects; on the one hand, an action is connected to his ability in reality, and on the other, his human ability is connected to God's ability. If the attribution of the action to Man is metaphorical rather than realistic, it means that the real world is a metaphor for the world of malakut (al-Ghazali 1983 (4): 256).

Al-Ghazali clarifies the concept of jabriyya in Man's actions through the quality of eternal ability, from which creation and invention are born; then his slaves, who were themselves his creation and invention, were divided into those whom God's eternal will arrived before, to be used to stop his wisdom before it achieved its goal, which compelled them by focusing His motives and impulses; and those whom His will reached before, to be used in eternity to drive his wisdom to its goal on certain issues (Ibid : 96). This description shows that the relationship between Man and his actions is compulsory. Man does not choose his actions and does not make his choices; he is the place where God's eternal will is fulfilled. Probably, a lot of puzzlement arises in the reader's mind and different questions regarding the meaning of the texts and al-Ghazali's explanations to the relationship between 'alam al-mulk (the corporeal realm) and 'alam al-malakut (the spiritual realm of sovereignty), between Man and God, be He exalted. Is it really a relation of Jabr, as al-Ghazali describes it?

If it is true that Man is judged as being compelled in his actions, the believer and disbeliever are alike, because God's will is expressed through them by compulsion, not by free choice; the believer is a believer by compulsion, and the disbeliever is a disbeliever by compulsion. Since "compulsion" comes from the asl (origin), why is the disbeliever punished for an action that he did not do, and of which he is not the real doer? If divine justice is based on this supposed "truth," is it fair to judge the human being for an action that he is compelled to do, or to judge him for his choice? It is necessary here to point out that al-Ghazali admits that this topic is too ambiguous to understand and too hard to make others understand (al-Ghazali 1983 (4): 255). 
The cause can be attributed to the borders of language, which are not wide enough to accommodate its meanings and their infinite abundance; in this realm, it lacks expressions worthy of the height of its position and is subject to the lowness of the position of language makers, whose understanding cannot reach the principles of its radiance(al-Ghazali 1983 (4): 95).

The relationship between the finite and the infinite, and the proportion between them, makes language unable to absorb the meanings or the named things of the World of malakut, and it cannot go beyond these borders. This explains why Sufism relies on the symbolic language of metaphors and majāz (allegory) to translate the truth of things from the spiritual world of malakut to the world of mulk and Shahada. It expresses the named things of that world through symbols and the named things of this world. The human being needs special knowledge of malakut, which al-Ghazali calls the world of the science of mukāshafa, which means the disclosure and uncovering of the Divine and the unveiling of the unseen:

Know that complete achievement of this is derived from the current of a great sea of mukashafat ... that are understood by the person who understand the logic of birds and deny them the one who is unable to clarify stories and unable to roam in the atmosphere of the malakut like a bird (al-Ghazali 1983 (4): 95).

This means that God's infinite knowledge of time and place includes God's knowledge of the actions of human beings. This previous knowledge of everything preceded the choices of human beings, and on it, human beings' will and ability are based. "The will necessarily includes knowledge, as well action necessarily includes the will (al-Ghazali 1993: 80). Their actions are originally voluntary and optional, but are done in light of God's knowledge as He teaches the believer and the disbeliever and leads them to their goals. The interconnection of the sciences of al-mukashafa and al-mu'amala in al-Ghazali leads the reader to feel that there is contradiction in his thought, but, in fact, it is an external contradiction if we realize that these two sciences of knowledge represent two differently ranked worlds, which entail different choices (ikhtiyar).

The chooser in the world of al-wujud (existence) chooses his actions by his senses and mind in a pure way, while the chooser in the world of shuhud exits from one stage into another, into the Spiritual World, uninterested in phenomena, and seeks the spirit. Attainment of this movement is not completed until the human being leaves his sensual and mental choices in the world of his existence (wujud), through his certain belief that God's choice is better and more beneficial. This chooser in the world of shuhud (witnesses) might rise one more degree to find that he has only one choice -to choose not to choose, and this compels him to abandon choice completely, not out of passivity and a desire to escape from responsibility, but out of more certainty that there is no goodness nor virtue, no attainment nor possession, except by choosing God, be He exalted. Thus, he does not choose not to choose, and finds himself in need of Him in his actions and attributes; the horizons of His hidden existence appear according to the degree of Man's necessity.

"The shuhud can rise to a higher degree, where they do not experience the faculty of choice, not because they are helpless to make decisions, but out of a complete certainty that if God did not give his faculty to His creatures, and if He did not give the boon to make choices, He would not attribute to Himself what He did, when He felt he is compelled to do that in Himself (Abd al-Rahman 2012 : 481). 
This elevation from wujud to shuhud does not cancel Man's relationship with the world of existence, nor his existential choices, as it is a moral elevation and an emancipatory choice to move from choice itself to his origin and soul, because there is no choice by certainty. Because to think about choice is to show doubt about choice, the movement from choice to necessity or Jabr (compulsion) is an exit from doubt to certainty, and an emancipation from the limitations of choice that the mind imposes on Man, which is freedom itself. The movement from wujud to shuhud or from ikhtiyar to Jabr is not contradictory from the point of view of the essence of the action. Choice is compulsion in the sense that it is subject to the rules of the mind that judge that an action is good. The human being is compelled to accept the ruling of the mind, and the human being is subject to the rule of God in the world of shuhud, and surrendering to God's judgment is better than reaching the world of shuhud and roaming in its wide space makes the human being forget his choices in the world of wujud, which is natural for someone who attains the ability to see what is behind causes and actions. It is impossible to keep clinging to doubt and probability after attaining right and certainty, because the clarity of the light of certainty is sufficient to satisfy one to give up the light of the mind, as the light of the sun is sufficient to give up the light of the stars.

The human being is likely to rise to a higher rank than one where he connects causes with their real causer by not seeing the many causes or things that exist in the world of wujud. He might even not see himself. He will not see anything in wujud except oneness, and due to his immersion in tawhid (oneness), unity and unification, he forgets himself, which is his fana' (annihilation) in tawhid which is the ultimate goal in Tawhid and the goal of mukashafat, which is impossible to dive into because revealing the secret of rububiyyah (the Oneness of Allah's Lordship) is infidelity and leads to disbelief in God (Al-Ghazali 1983(4): 246). Annihilation is the abolishment of all al-mawjudat (existents/beings) and a retreat to the beginning and the origin of mawjudat - God, be He exalted. The human being who returns to that is compelled to abolish everything, so that it will be possible for him to reach the First. In addition, the one who reaches the origin will do without the branches that lead to him. The one who reaches this rank gives up questioning because of the clarity of the One who is responsible for him; thus, there is no point in asking or thinking in the presence of the Almighty One. In the case of annihilation, the relationship between Man and God, be He exalted, is a relation of total submission: "Indeed for Ghazali the conception of man as "the corpse in the hands of the washer" is a central religious motif well suited to the development of a proper appreciation of the nature of finite existence in relation to God" (Goodman 1978).

Al-Qushayrī says in his treatise: "He who is controlled by the sovereignty of the truth so that he could not witness any other person or trace of an image or a ruin is said to be annihilated away from humans and remained with the Right" (al-Qushayri 1957: 36). He defines three stages of one's annihilation: "One's passing away from himself and his attributes by keeping to the attributes of Right. Then his passing away from the attributes of the Right by the witnesses of the Right. Then his passing away from the witnesses of his passing away by his consumption in the Existence of the Right (Ibid, 36). Al-Jabiri believes that "Unity of Witnesses" means avoidance of a declaration of the "Unity of Existence" because the seer and the seen are in any case "two existences" and when they are unified, they become one existence, istihlāk (consumption) in one existence, with the annihilation of witnesses of that existence, means identification with that existence, and this is the unity of existence itself (Ibid: 37).

It is necessary to distinguish between the world of wujud and the world of shuhud. They are two different worlds; neither of them can substitute for the other, and they cannot be considered one thing. They can be seen as equivalents of 'alam al-mulk and 'alam malakut. The world of shuhud is a spiritual world to which the human being rises; forgetting everything except the existence of God, the Right, and it is a mortal one that passes away from others. Thus, it is neither a witnessing unity nor 
an existential one. The relationship between the seer/witnessing and the seen/witnessed is a relationship between two different entities. Furthermore, if man sees nothing in the world except God, that does not mean unity of existence nor the unity of God with existence; unity lies in Man's seeing the presence of God in everything, i.e., seeing this as a creation of God and His invention.

The justice of God, be He exalted, requires that choosing should precede requesting, as the human being chooses and bears responsibility for his choices. There is no responsibility without choice, and choice is the condition for responsibility; the absence of responsibility and the capture of Jabr eliminate questioning; otherwise, it would be injustice that contradicts justice, whereas God's justice is pure and has no injustice. It is possible to say that the human being in the world of reality chooses his actions according to his senses and his mind. This choice is proportionate with the degree of his physical and mental abilities, from the point of view of the goodness of his choice, and in this case, he is a chooser. "In Ghazali's case the man under the date tree has the reasons for going the other way. They are his reasons. He picks date A but has no arguments against picking date B" (Normore 2007: 56). Man is naturally disposed to make choices, and he cannot do but choose, which is an essential subjective part of Man and the effective value in the humanity of the human being. This means that Man does not exist without choice. The more the scope of his choice increases and the reach of his actions expands, the more his humanity is expanded and augmented, and vice versa. If choice as a value is achieved in Man, its existence becomes relative, but it is connected to the absolute value and aspires to it out of a longing for perfection and completion.

\section{Causality and Reliance}

Al-Ghazali defines reliance as dependence of the heart on al-wakeel (the Trustee/ God)(al- Ghazali 1983 (4): 259). It seems that this definition contradicts, though superficially, that of causality, because Man's reliance on the other in his actions lowers the connection of actions with their causes. Al-Ghazali, however, turns this contradiction into reconciliation by returning the causes to their origins. Al-Ghazali confirms that "all the doors of belief are not regularized except by knowing their origin (source) and the action is the fruit and the spiritual state is twakul (reliance) on God"(Ibid: 245). Achievement of knowledge and action are two conditions for reaching the spiritual state, which is the reliance (on God) that is considered one of the doors of belief, whose source is tawhid; tawakkul is connected to knowledge and work, and it is not independent in its establishment and existence. "In standard Sufi terminology, the hal was a gift of God. It did not result from the individual person's striving or effort fi sabil Allah, "along the path of God", rather, reaching this spiritual state depended not upon the mystic but upon God" (Bargeron 2003: 55).

"Achievement of Reliance as a lived Spiritual State in the life of the dependent Man occurs if he is certain of four things in the Wakeel (the Trustee/God)" (al-Ghazali 1983 (4): 260). the utmost degree of guidance, the utmost degree of power, the utmost degree of eloquence, and the utmost degree of mercy. The decisive belief that there is no doer except God, who has complete knowledge and the ability to satisfy the worshippers of God; the complete care and mercy of worshippers and individuals; and the belief that there is no other ability above His ability, no knowledge above His utmost knowledge, no care above His utmost care, no mercy above His utmost mercy to the human being, makes your heart inevitably rely only on Him, and it will not turn to any other face or soul or ability. "Understanding that God has such pre-knowledge represents a higher degree of trust in God than relying on conclusions drawn from God's habits. This higher trust in God is closely linked to the proper understanding of divine Tawhid. Indeed, advancing to the higher stages of tawhild is the root that helps one develops this superior trust in God (Griffel 2009: 18). 
Absence of this spiritual state is attributed to a weakness of belief in, and a lack of certainty of, one of the four qualities, or to a weakness of the heart and its sickness, as a result of its capture by cowardice and its annoyance by illusions that dominate it. This differentiation between certainty and the heart is due to the possibility of achieving certainty without tranquility or achieving tranquility without certainty. The believer can be certain, but not tranquil or secure, because cowardice and bravery are instincts that are not based on certainty. The spiritual state of tawakkul differs between mutawakkilin (dependents) and God with regard to weakness and power. It also differs in the dependent (mutawakkil) between addition and reduction or between abundance and shortage, as it is not a fixed spiritual state. It occurs in three different degrees (Ormsby 2008: 131):

1. The mutawakkil should trust in God's care and His guardianship.

2. The mutawakkil dependent should annihilate himself in his dependence, for his dependence. The dependent's heart does not turn to dependence (reliance) and its truth, but to God, the only Trustee (Wakeel).

3. The difference between the Hal (spiritual state) of the mutawakkil in the two degrees lies in the fact that the dependent's reliance in the first degree is done through takalluf (straining) and kasb (acquisition). He pays attention to his dependence and feels it, and this distracts him from noticing the relied upon only. The second mutawakkil rises to the degree of annihilation, which implies abandonment of choice. "He won't argue that we should trust in God because He is the 'necessarily existing being' from whom all existence and all good flow. Nor does he hold, with his Ash'arite colleagues, that we should trust because whatever God wills, instant after instant, is good simply because God willed it, without regard for man's benefit or indeed, for any discernible purpose. But God wills the good in everything, and in everything He wills there is benefit to humankind".

The spiritual state in which the mutawakkil is certain that he is a channel of the movement, ability, will, knowledge and other divine attributes, each taking place compulsorily, is unaware of what is happening to him. Al-Ghazali compares him to a baby who knows about his mother, though he does not cry for her, and his mother demands him. He knows also that even if he did not cling to his mother, she would carry him. If he did not ask for milk, his mother would initiate to feed him. This rare high status leads the dependent to stop calling on God and asking for something from Him because he has trust in God's generosity and care, while in the second degree he does not have to leave his calling on God and asking from Him, but he should leave off asking from others.

One might ask about the status of causes in al-mutawakkil's actions and the management of his daily life: What is the relationship between reliance on God and the management of livelihood and life, which cannot be sustained except by work and diligence, and work that is conditioned by understanding causes and their relationship with their outcomes? Al-Ghazali answers this question through his clarification of the relationship between management and reliance on God. He admits that the second and third degrees are denials of management and of complete reliance on the Wakeel (Trustee/God). However, the first degree does not deny management and choice, but rejects certain forms of management. This means that the mutawakkil on God manages his daily life affairs according to choices that are based on his senses and mind, and he chooses his actions and is not compelled to do them, but the achievement of these actions is made possible within the limits of God and His signs, or according to divine traditions and customs, rather than His explicit signs.

The meaning of management in this context is the administration of political and economic issues and other fields of life. This management can occur at different levels: management of the individual, management of society, and management of the state. The mutawakkil, first and foremost, 
conducts his secular actions of daily living and acts in the presence of God and the soul of His teachings, which God drew for Man. The muawakkil does not attribute his actions to himself nor other people, but to God only, as God is present in his actions. Management can also be done without direct and explicit hints or signs from God, as the mutawakkil depends on his known traditions and the steadiness of his rules. In other words, he depends on God's laws and rules for His creation and nature. God's traditions, rules, and norms appear in the universe and nature through their consecutive, regular, and steady regularities. The dependent's (mutawakkil's) secular actions should be considerate of God's rules and the clear limits set in his unseen written Book, and of God's universal actions in His seen Book.

The achievement of this reliance on God cannot be fulfilled except by attaining the knowledge of the two books, i.e., by acquiring a grasp of the religious ethical sciences, the mental theoretical sciences, and the empirical natural sciences. Mastering these sciences is a condition for tawakkul, and each deficit in knowledge of these sciences is a diminishment of reliance. After their accomplishment, the mutawakkil is ready to rise to the second and third degrees. The connections among reliance, management, and work are clear indications that abstention from secular life, abandoning its interests and goals and resorting to isolation, have nothing to do with reliance, as reliance is fulfilled only through active participation in managing the fields of political, economic, and scientific life, and issues that concern people's livelihood and their life interests. Al-Ghazali does not deny the difficulty of achieving reliance in the real world in its three degrees/ranks, but it is possible, especially in the first degree, which is closest to possibility and accomplishment. Al-Ghazali compares the constancy of this state to the paleness of the patient whose disease controls him; it might either stay or go away. He compares the second rank/degree to the paleness of the fevered patient, whose fever might continue for a day or two. The third rank/degree is compared to the paleness of fear, which might continue for a very short time or not continue at all.

To summarize, Al-Ghazali seeks to revive the necessary relationship between Man and God, be He exalted, considering it the beginning of beginnings, the end of ends, and the origin of relations. Unity is the existential origin and epistemological ideal from which the relationship between Man and himself, and between humans and nature, are derived. The establishment of human work in sense and mind is based on the science of unity, which guarantees that the process of human work will reach the goal for which Man was born. Man's awareness of himself, that he is not the source of his existence, is attributable to the founder of existence and its Creator, and Man is not an epistemological ideal that produces the truths of things as they are. When Man realizes the truth of his existence and knowledge, he will realize that he does not realize the truths of existence. Selfawareness is Man's perception of his helplessness regarding his existential and epistemological perception, and his helplessness at perceiving the necessity of communication with God. God's will decided that the human being will be an honored creature that is preferred to the rest of creatures, and one of the signs of this honor is that he is "chosen" and responsible for his actions.

Freedom of choice is a quality that characterizes wise people who can distinguish among choices in order to choose the best actions to benefit their lives. The chooser resorts to his sense and mind in his choice of his actions, hoping to achieve the utmost goodness. When Man realizes the limitations of the mind in his making of choices, he resorts to the first principle, from which existence was created, in an attempt to know the existential origin of existence, out of a desire for his certain goodness. This resorting to the asl (origin) is a request for divine support to guide human actions towards their destinations, and it should not be understood as an abandonment of action, but as a choice of the best and most preferable ones. It is right to say that communication with the asl (origin) aims to expand the borders of the mind and connect it with absolute, existential truths.edmund 


\section{References}

Abd al-Rahman Taha. 2012. Ruh al-Din, Al-Dar al-Baydha'. n.l. Al-Markiz al-Thaqafi al-Arabi. Alon, Ilai. 1980. Al-Ghazali on causality. Journal of the American Oriental Society. 100 (4): 397-405. Bargeron, Carol, L. 2003. Sufism' Role in al-Ghazali's first crisis of knowledge. Medieval Encounters. $32: 78,9,1$.

De Cillis, Maria. 2014. Free Will and Predestination in Islamic Thought. New York: Routledge. Al-Ghazali. 1983. Ihya'a 'Ulum al-Din. Beirut: Dar al-Fikr.

Al-Ghazali. 1988. al-Iqtisad fil-I'tiqad. Beirut: Dar al-Kutub al-'Ilmiyah.

Al-Ghazali. 1993. Tahafut al-Falasifa. n.l. Dar al-Fikr al-Lubnani.

Goodman, Lenn Evan. 1978. Did Al-Ghazâlî deny causality?". Studia Islamica. 47: 83-120.

Griffel, Frank. 2009. Al-Ghazali's Philosophical Theology. Oxford Scholarship Online. http://www.oxfordscholarship.com/view/10.1093/acprof:oso/9780195331622.001.0001 /acprof-9780195331622.

Hourani, George F. 1976. Ghazali on the Ethics of Action. Journal of the American Oriental Society. 96 (1): 69-88.

Leaman, Oliver. 1996. Ghazali and the Ash'arites. Asian Philosophy: An International Journal of the Philosophical Traditions of the East. 6 (1): 17-27.

Macksood, Aftab. 2015. Is Islam committed to dualism in the context of the problem of free will?. Journal of Cognition and Neuroethics. 3 (1): 1-12.

Marmura, Michael E. 2002. Ghazali and Ash'arism revisited. Arabic Sciences and Philosophy. 12: 91110.

Naify, James. 1999. Al-Ghazali. The Columbia History of Western Philosophy. Edited by Richard H. Popkin. New York: Columbia University Press.

Normore, Calvin. 2007. Freedom, Contingency, and Rational Power. Proceedings and Addresses of the American Philosophical Association. 81 (2): 49-64.

Ormsby, Eric L. 2008. Ghazali: The Revival of Islam. Oxford: One World.

Pennings G.J. 1941. God's decrees and man's responsibility. The Muslim World. 31 (1): 23-28.

Awn, Peter J. 1983. The Ethical Concerns of Classical Sufism. The Journal of Religious Ethics. 11 (2): 240-263.

Power, Edmund. 1913. Fatalism and free will in Islam. Studies: An Irish Quarterly Review. 2(5/Mac): 860-872.

al-Qushayri. 1957. al-Risala al-Qushayriyya fi 'Ilm al-Tassawwuf. Beirut; Dar al-Kitab al-'Arabi.

al-Shahrastani. 1986. al-Milal wa al-Nihal. (1). Beirut: Dar Sa'b.

al-Taftazani. 1989. Sharh al-Maqasid. Beirut: 'Alam al-Kutub.

Zaroug, Abdullahi Hassan. 1997. AI-Ghazali's sufism: a critical appraisal. Intellectual Discourse. 5 (2): 145-167. 